\title{
KELIMPAHAN DAN POLA SEBARAN REMIS Donax sp. DI PANTAI BATU BEDAUN DAN PANTAI BERIGA BANGKA BELITUNG
}

\section{ABUNDANCE AND PATTERN OF BEAN CLAMS Donax sp. DISTRIBUTIONS AT BATU BEDAUN BEACH AND BERIGA BEACH BANGKA BELITUNG}

\author{
Suarman', Umroh ${ }^{1, *}$, Kurniawan ${ }^{1}$ \\ ${ }^{1}$ Jurusan Manajemen Sumberdaya Perairan, Fakultas Pertanian Perikanan dan Biologi, \\ Universitas Bangka Belitung, Indonesia \\ •email penulis korespondensi: Armanasus9@gmail.com
}

\begin{abstract}
Abstrak
Penelitian untuk mengetahui kelimpahan dan pola distribusi Remis (Donax sp) di Pantai Batu Bedaun dan Pantai Beriga Provinsi Kepulauan Bangka Belitung pada Bulan Maret 2017. Penentuan lokasi pengambilan sampel dilakukan dengan metode Purposive Sampling. Pengambilan sampel dilakukan pada 2 lokasi dan masing-masing 3 stasiun dengan 4 kali ulangan. Parameter fisika dan kimia yang diukur meliputi: suhu, salinitas, kelembaban, pH, substrat dasar perairan, sedangkan pengukuran substrat dasar perairan dilakukan di Laboratorium Manajemen Sumberdaya Perairan, Fakultas FPPB (Pertanian, Perikanan dan Biologi) Universitas Bangka Belitung. Hasil penelitian menunjukkan bahwa kelimpahan populasi Remis (Donax sp) di Pantai Batu Bedaun Kecamatan Sungailiat berkisar antara 6 - 16 ind $/ \mathrm{m}^{2}$. Analisis kelimpahan secara umum menunjukkan tingkat kelimpahan yang rendah, sedangkan di Pantai Beriga Kecamatan Lubuk Besar berkisar antara 151 - 194 ind $/ \mathrm{m}^{2}$ dan kelimpahan secara umum menunjukkan tingkat kelimpahan yang cukup tinggi. Analisis indeks Morisita secara umum menunjukkan Pola sebaran Remis (Donax sp) di Pantai Batu Bedaun Kecamatan Sungailiat termasuk kategori merata (Id < 1), sedangkan di Pantai Beriga Kecamatan Lubuk Besar termasuk kategori mengelompok (Id > 1).
\end{abstract}

Kata Kunci: Kelimpahan, Pola sebaran, Remis (Donax sp), Pantai Batu Bedaun dan Beriga, Indeks Morisita

\begin{abstract}
Research to find out the abundance and distribution pattern of Bean Calms (Donax sp) at Batu Bedaun Beach and Beriga Beach at Province of Bangka Belitung Island in March 2017. Determination of sampling location was done by Purposive Random Sampling method. Sampling was done at 2 locations and each of 3 stations with 4 replications. Physical and chemical parameters measured include: temperature, salinity, humidity, $\mathrm{pH}$, substrate base of waters, while the measurement of the bottom substrate of the waters was conducted in the Water Resource Management Laboratory, Faculty of (Agriculture, Fisheries and Biology) University of Bangka Belitung. The results showed that the population abundance of Bean Calms (Donax sp) in Batu Beach Bedaun of Sungailiat Subdistrict ranged between $6 \mathrm{ind} / \mathrm{m}^{2}-16 \mathrm{ind} / \mathrm{m}^{2}$. Abundance analysis in general shows low abundance, whereas in Pantai Beriga Kecamatan Lubuk Besar ranges between 151 ind $/ \mathrm{m}^{2}-194 \mathrm{ind} / \mathrm{m}^{2}$ and abundance in general shows high enough abundance. Morisita index analysis in general shows the pattern of distribution of Bean Calms (Donax sp) in Batu Bedaun Beach, Sungailiat Subdistrict, including uneven category $(\mathrm{Id}<1)$, whereas in Beriga Beach Lubuk Besar Subdistrict is classified as $(\mathrm{Id}>1)$.
\end{abstract}

Keywords: Abundance, Pattern of distribution, Bean Calms (Donax sp), Batu Bedaun and Beriga Beach, Morisita Index

\section{PENDAHULUAN}

Provinsi Kepulauan Bangka Belitung merupakan suatu daerah atau wilayah yang terkenal dengan penghasilan Sumberdaya pesisir. Provinsi Kepulauan Bangka Belitung merupakan aset daerah yang dapat dimanfaatkan untuk meningkatkan kesejahteraan 
masyarakatnya. Potensi sumberdaya yang ada salah satunya adalah kerang-kerangan dan siput. Kepulauan Bangka Belitung selama ini telah dimanfaatkan oleh masyarakat pesisir di wilayah tersebut dengan berbagai cara. Tingkat pemanfaatan yang cukup intensif pada jenis-jenis tertentu menyebabkan keberadaan sumberdaya tersebut kini semakin berkurang. Untuk mewujudkan pola pemanfaatan biota kekerangan dan siput dapat terus berlangsung serta kelestariannya tetap terjaga diperlukan pola pengelolaan yang tepat dengan melibatkan stake holder yang ada.

Pantai Batu Bedaun terletak di kampung Bukit Kuala, Kelurahan Matras, Kecamatan Sungailiat Kabupaten Bangka. Pantai ini cukup unik, bersebelahan dengan Pantai Parai Tenggiri. Pantai ini dinamakan Pantai Batu Bedaun karena ada pulau kecil yang hanya terdiri dari batu-batu besar dan sebatang pohon yang tumbuh di tengah-tengahnya. Pantai Batu Bedaun saat ini terdiri dari kegiatan wisata pantai dan aktivitas pendaratan ikan oleh nelayan tradisional. Pantai Batu Bedaun memiliki keunikan berupa batu granit besar dengan hamparan pasir putih dan laut biru. Pantai Batu Bedaun banyak terdapat Remis (Donax denticulatus) yang sering dicari masyarakat untuk di konsumsi.

Pantai Bariga merupakan pantai yang berada di Desa Batu Beriga Kecamatan Lubuk Besar Bangka Tengah, yang terletak 21,8 km dari Kecamatan Lubuk Besar dan $55 \mathrm{~km}$ dari Kabupaten Bangka Tengah. Desa Batu Beriga mempunyai luas wilayah seluas $10.873 \mathrm{Ha}$.
Pantai ini merupakan tempat masyarakat mencari hasil tangkapan laut seperti ikan, kerang, cumi-cumi, udang, dan Remis. Remis juga salah satu hasil laut yang dimanfaatkan masyarakat Batu Beriga sebagai lauk pauk atau untuk konsumsi.

Remis merupakan salah satu komponen penting dalam ekosistem perairan baik sebagai komponen rantai makanan, maupun sebagai indikator pemantauan kualitas perairan, dikatakan penting yaitu dikelompokan kedalam filter feeder yaitu bentos yang mengambil makanan dari permukaan dan dalam substrad dasar perairan (Setyobudiandi et al., 2009). Remis memiliki sifat hidup relatif menetap atau tidak berpindah-pindah, meskipun kualitas air tidak mengalami perubahan. Remis juga memiliki rentang hidup hingga dua tahun (bergantung pada jenisnya) (Junaidi et al., 2009).

Remis memiliki peranan dalam rantai makanan, selain itu Remis juga dimanfaatkan warga sebagai bahan konsumsi. Wilayah pesisir Pulau Bangka khusus Kecamatan Sungailiat dan Kecamatan Lubuk Besar tidak semuanya memiliki potensi Remis. Potensi Remis berdasarkan informasi dari masyarakat Provinsi Kepulauan Bangka Belitung salah satunya terdapat di Pantai Batu Bedaun dan Pantai Beriga. Potensi kelimpahan dan pola sebaran Remis belum diketahui, dengan demikan perlu adanya penelitian mengenai kelimpahan Remis dan pola sebaranya untuk pemanfaatan dimasa yang akan datang.

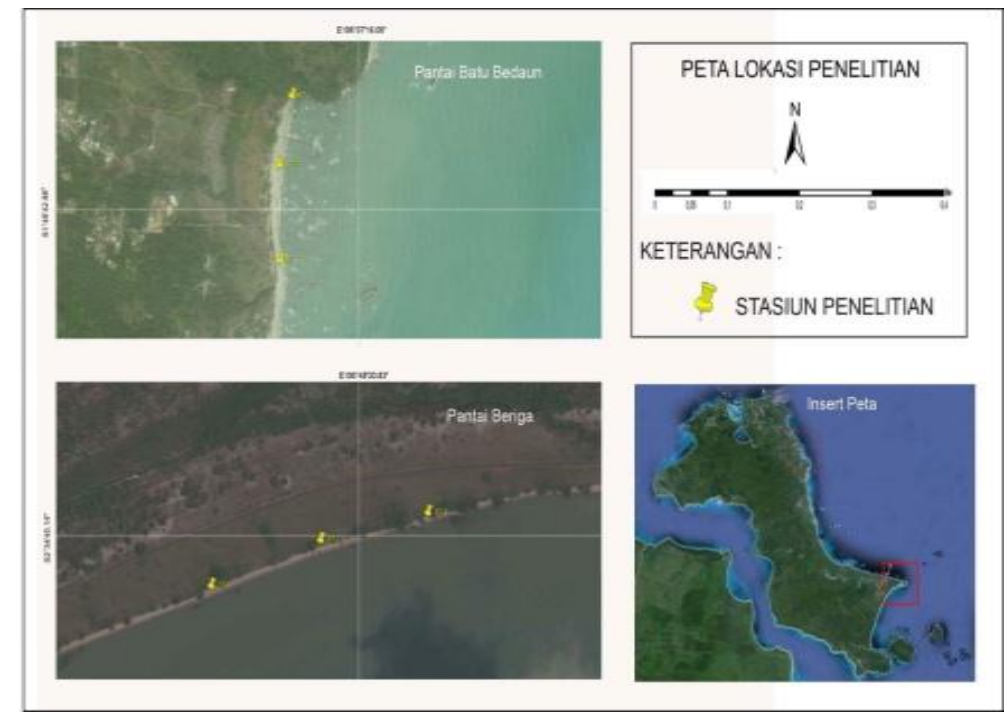

Gambar 1. Peta lokasi peneitian.

\section{MATERI DAN METODE}

Penelitian ini dilaksanakan pada Bulan Maret 2017 di lokasi Pantai Batu Bedaun dan
Pantai Beriga Kabupaten Bangka (Gambar 1) dan sampel di uji pada laboratorium Manajemen Sumberdaya Perairan Fakultas FPPB (Pertanian, 
Perikanan dan Biologi) Universitas Bangka Belitung. Alat yang digunakan dalam penelitian ini yaitu, Transek kuadrat (ukuran 1x1 m), baskom, pH meter, refraktometer, termometer, dan ayakan pasir, roll meter, cangkul,wareng (ukuran 1x1 m), serta kantong plastik. Bahan yang digunakan dalam penelitian ini yaitu hasil Remis dan substrat sebagai objek dalam penelitian. Data hitungan untuk mengetahui data kuantitatif, literatur-literatur dalam membantu menulis hasil penelitian dan menunjang data hasil.

\section{Metode Pengambilan Data}

Penelitian ini observasional yaitu pengamatan langsung ke lapangan terhadap kelimpahan dan Sebaran Remis di Pantai Batu Bedaun dan Pantai Beriga Provinsi Kepulauan Bangka Belitung. Penentuan stasiun pengambilan sampel dilakukan setelah survei lokasi dengan menggunakan metode Purposive Sampling stasiun pengamatan di Pantai Batu Bedaun dan Pantai Beriga. Metode Purposive Sampling adalah metode penentuan stasiun berdasarkan pertimbangan peneliti yang dapat dilihat pada tabel dibawah.

Data yang dikumpulkan berupa data primer dan data sekunder. Data primer berupa hasil pengukuran parameter. Hasil pengukuran Remis yang di peroleh langsung dari lapangan. Pengumpulan data sekunder dilakukan dengan cara mengumpulkan informasi berupa lokasi yang umum masyarakat dalam mencari Remis di Pantai Batu Bedaun dan Pantai Beriga Kabupaten Bangka.

Pengambilan data Remis dilakukan dengan menggunakan transek kuadrat $1 \times 1 \mathrm{~m}$ pada rollmeter sepanjang 100 meter yang diletakkan sejajar garis pantai. Peletakan transek kuadrat dilakukan secara acak. Setiap stasiun terdapat 3 transek kuadrat dan dilakukan 4 kali ulangan dalam pengambilan data. Data remis diambil dengan menggunakan cangkul secara keseluruhan yang termasuk kedalam area transek, kemudian diayak menggunakan wareng sebagai alat bantu pemisahan remis dari pasir (Setyobudiandi et al., 2009).

\section{Analisis Data}

Analisis Kelimpahan.

Analisis data Kelimpahan populasi Remis dilakukan dengan menghitung jumlah Remis yang didapatkan berdasarkan Junaidi et al., (2010). Selanjutnya data yang diperoleh dihitung dengan rumus sebagai berikut :

$$
\mathrm{N}=\frac{\mathrm{S}}{\mathrm{A}}
$$

Keterangan :

$\mathrm{N}$ : Kelimpahan Per $\mathrm{m}^{2}$

S : Jumlah Rata-rata Individu Remis Yang didapat A : Luas area cetakan $1 \mathrm{~m} \times 1 \mathrm{~m}$.

\section{Analisis Pola Sebaran}

Komposisi pemanfaatan seluruh data hasil tangkapan (Ht) yang dimanfaatkan dibandingkan dengan hasil tangkapan yang tidak dimanfaatkan (discard) dalam bentuk proporsi dengan rumus. Tabel hasil tangkapan tersebut dinyatakan dalam kg dan ekor (Ramdhan, 2008) :

$$
I D=\frac{n\left(\sum_{i=1}^{n} X^{2}-N\right.}{N(N-1)}
$$

Keterangan :

ID : Indeks sebaran Morishita,

$\mathrm{n}$ : Jumlah ulangan pengambilan contoh,

xi : Jumlah individu pada setiap ulangan pengambilan contoh, dan

$\mathrm{N}$ : Jumlah individu total yang diperoleh dalam pengambilan contoh.

\section{Kriteria Indeks sebaran :}

Id $<1$ berarti penyebaran spesies secara merata Id $=1$ berarti penyebaran spesies secara acak Id $>1$ berarti Penyebaran mengelompok

\section{HASIL}

Hasil pengamatan terhadap kelimpahan Populasi Remis (ind $/ \mathrm{m}^{2}$ ) yang telah dilakukan pada dua lokasi berbeda pengamatan di Pantai Batu Bedaun dan Pantai Beriga disajikan pada Gambar 2. Pola penyebaran dari spesies Remis selama pengamatan dapat dianalisis dengan menggunakan Indeks Penyebaran ialah Indeks Sebaran Morisita. Pola penyebaran Remis dapat dilihat pada Tabel 1. Pengukuran kualitas perairan laut yang telah dilakukan selama penelitian ini didapatkan nilai yang berbeda antara stasiun.

Kualitas perairan Pantai Batu Bedaun dan Pantai Beriga disajikan pada tabel 2. Hasil analisa menggunakan sieve shaker. Sedimen yang berukuran $0.25 \mathrm{~mm}$ rata-rata sebanyak $77.56 \%$ terdapat pada Pantai Batu Bedaun, sisanya $20.07 \%$ yaitu sedimen debu dan $1.18 \%$ sedimen lempung, dan Sedimen yang berukur $0.25 \mathrm{~mm}$ rata-rata sebanyak $97.67 \%$, sisanya $2.28 \%$ sedimen debu dan $0.01 \%$ sedimen lempung yang terdapat pada Pantai Beriga (Tabel 3)

\section{PEMBAHASAN}

Berdasarkan hasil pengamatan sampel Remis yang telah dilakukan di lokasi penelitian pada bulan Maret 2017 di Pantai Batu Bedaun dan Pantai Beriga, didapatkan kelimpahan Remis 
berkisar antara $6-17$ ind $/ \mathrm{m}^{2}$, sedangkan di Pantai Beriga berkisaran 151 - 194 ind $/ \mathrm{m}^{2}$. Kelimpahan populasi tertinggi ditemukan pada Pantai Beriga pada stasiun I yaitu $151 \mathrm{ind} / \mathrm{m}^{2}$, stasiun II yaitu $174 \mathrm{ind} / \mathrm{m}^{2}$ dan stasiun III yaitu sebanyak 194 ind $/ \mathrm{m}^{2}$, sedangkan terendah pada Pantai Batu Bedaun stasiun I yaitu 16 ind $/ \mathrm{m}^{2}$, stasiun II yaitu $6 \mathrm{ind} / \mathrm{m}^{2}$, dan stasiun III yaitu sebanyak $13 \mathrm{ind} / \mathrm{m}^{2}$ dan dapat dilihat pada Gambar 2.
Kelimpahan populasi pada Pantai Beriga lebih tinggi dibandingkan dengan Pantai Batu Bedaun, hal ini disebabkan oleh kondisi substrat pada Pantai Beriga lebih cocok dibandingkan Pantai Batu Bedaun, dan dapat dilihat dari tabel 3. Pantai Beriga bersubstrat pasir, sedangkan di Pantai Batu Bedaun terdapat substrat lempung berpasir. Analisis kimiawi menunjukkan substrat di Pantai Batu Bedaun terlalu banyak lempung (liat) akibat dari aktivitas tambang yang masih beroperasi di Pantai Batu Bedaun.

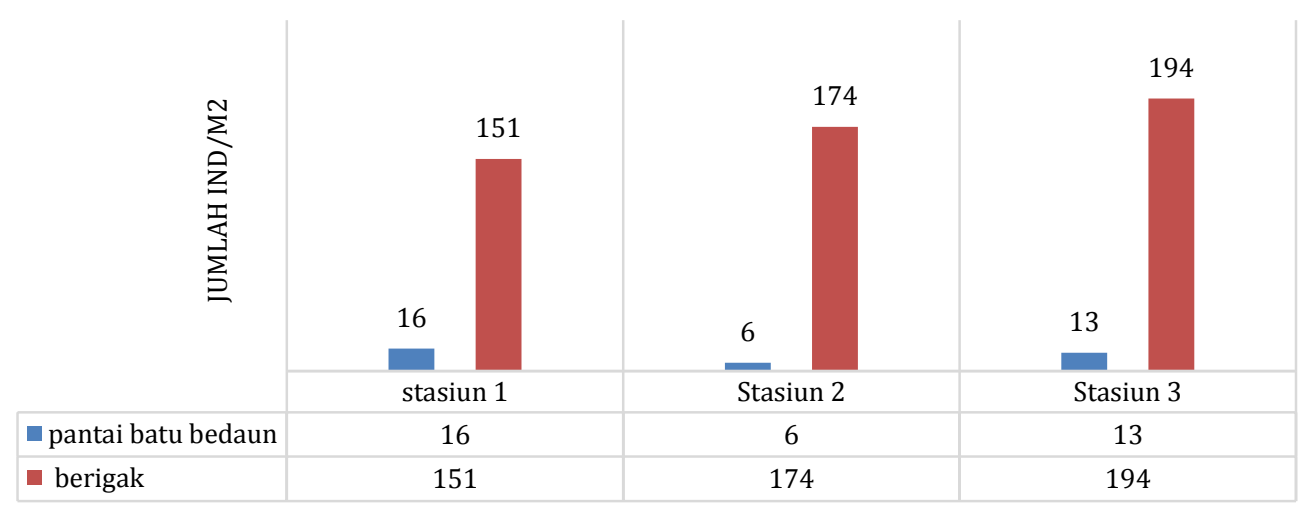

Gambar 2. Nilai rata-rata kelimpahan remis di Pantai Batu Bedaun dan Pantai Beriga.

Tabel 1. Indeks penyebaran dan pola penyebaran Remis

\begin{tabular}{rccccc}
\hline Batu Bedaun & Indeks Morishita & Pola Sebaran & Beriga & Indeks Morishita & Pola Sebaran \\
\hline Stasiun 1 & 0,926 & Merata & Stasiun 1 & 1,075 & Mengelompok \\
Stasiun 2 & 0,778 & Merata & Stasiun 2 & 1,208 & Mengelompok \\
Stasiun 3 & 0,882 & Merata & Stasiun 3 & 1,092 & Mengelompok \\
\hline
\end{tabular}

Tabel 2. Nilai rata- rata pengukuran parameter lingkungan

\begin{tabular}{clccccccc}
\hline \multirow{2}{*}{ No } & \multirow{2}{*}{ Parameter } & \multicolumn{9}{c}{ Pantai Batu Bedaun } & \multicolumn{3}{c}{ Pantai Beriga } & \multirow{2}{*}{ Baku mutu } \\
\cline { 2 - 7 } & St 1 & St 2 & St 3 & St 1 & St 2 & St 3 & \\
\hline 1 & Suhu & 30 & 30 & 30 & 29 & 29 & 29 & 29-31 ${ }^{\circ}$ C(Ferdiansyah et al., 2015). \\
2 & Salinitas & 28 & 29 & 29 & 29 & 29 & 29 & 27-29\%o (Ferdiansyah et al., 2015). \\
3 & pH Air & 6 & 7 & 7 & 6 & 7 & 7 & 6-7 (Bahri., 2006). \\
4 & pH Tanah & 5,5 & 5 & 5 & 5 & 5 & 5 & 5-9 (Junaidi et al., 2010) \\
5 & Kelembapan & 6 & 6 & 6 & 6,5 & 6,5 & 6 & 6-7,5(Romimohtarto, 2009). \\
\hline
\end{tabular}

Tabel 3. Kondisi substrat Pantai Batu Bedaun dan Pantai Beriga

\begin{tabular}{ccccccccc}
\hline \multirow{2}{*}{ St } & \multicolumn{9}{c}{ Pantai Batu Bedaun } & \multicolumn{3}{c}{ Pantai Beriga } \\
\cline { 2 - 9 } & Pasir \% & Debu \% & Liat \% & Type Substrat & Pasir \% & Debu \% & Liat\% & Type Substrat \\
\hline 1 & 67.99 & 29.24 & 2.78 & $\begin{array}{c}\text { Lempung } \\
\text { berpasir }\end{array}$ & 97.09 & 2.88 & 0.02 & Pasir \\
2 & 76.16 & 23.79 & 0.05 & $\begin{array}{c}\text { Lempung } \\
\text { berpasir }\end{array}$ & 98.53 & 1.47 & 0 & Pasir \\
3 & 72.11 & 27.20 & 0.7 & $\begin{array}{c}\text { Lempung } \\
\text { berpasir }\end{array}$ & 97.11 & 2.88 & 0,01 & Pasir \\
\hline
\end{tabular}

Menurut Riniatsih et al., (2009) menunjukan bahwa kelimpahan Remis disubstrat berpasir lebih tinggi jika dibandingkan dengan substrat lempung berpasir, hal ini disebabkan kandungan jenis substrat dan jenis partikel merupakan faktor lingkungan yang berpengaruh terhadap kelimpahan Remis, karena masing-masing jenis Remis mempunyai cara hidup yang berbeda yang disesuaikan dengan jenis substrat dasar habitatnya. Kisaran nilai persentase kandungan liat dasar perairan di Pantai Batu Bedaun sebesar
1,18\%, sedangkan Pantai Beriga nilai persentase kandungan liat sebesar 0,01 \%. Analisis kimiawi menunjukan substrat di Pantai Batu Bedaun terlalu banyak lempung (liat) akibat dari aktivitas penambangan yang masih beroperasi di kawasan Pantai Batu Bedaun tersebut.

Kelimpahan Remis di Pantai Batu Bedaun lebih sedikit dari Pantai Beriga juga disebabkan masuknya limbah rumah tangga maupun dari padatnya wisatawan yang datang ke Pantai Batu Bedaun sehingga sebaran limbah tersebut 
menjadi lebih luas di Pantai Batu Bedaun dibandingkan dengan Pantai Beriga, sampah yang masuk ke badan air tidak mampu dinetralisasi dengan segera. Menurut Junaidi et al., 2010 Kelimpahan bisa bekurang karena Remis akan merasa terganggu pada tingkat kebisingan dan bisa merasa terganggu dengan adanya aktivitas manusia seperti penambangan, serta tingginya wisatawan yang dapat menyebabkan tingginya limbah tersebut.

Kelimpahan populasi Remis pada Pantai Batu Bedaun sangatlah rendah, dikarenakan keadaan suhu air di daerah Pantai Batu Bedaun cukup tinggi dibandingkan dengan Pantai Beriga dapat dilihat pada tabel 1 , hal ini dikarenakan dampak limbah yang terlalu banyak yang disebabkan oleh wisatawan maupun dari pemukiman warga sekitar. Menurut Junaidi et al., (2010) limbah thermal menjadi lebih luas ketika kondisi perairan dalam keadaan surut sehingga limbah thermal yang masuk ke badan air tidak mampu dinetralisasi dengan segera. Keadaan tersebut membuat suhu air di daerah yang terkena dampak menjadi lebih tinggi sehingga organisme yang tidak toleran terhadap suhu tinggi akan mati atau bermigrasi.

Pola Sebaran diartikan sebagai susunan anggota populasi dalam satuan waktu dan suatu ruang. Hasil hitungan Indeks Morisita Remis pada 2 lokasi pengamatan yaitu di Pantai Batu Bedaun dan Pantai Beriga Provinsi Kepulauan Bangka Belitung pada bulan Maret 2017, dapat dilihat pada tabel 1. Hasil analisis Indeks Morisita, pola sebaran Remis di Pantai Batu Bedaun mempunyai pola sebaran merata (uniform) pada ketiga stasiun pengamatan, Hal ini didapat berdasarkan hitungan indeks Morisita dengan nilai perstasiun dengan nilai kriteria Id $<1$ dimana berarti penyebaran spesies merata, sedangkan pola sebaran Remis pada Pantai Beriga di 3 stasiun pengamatan penyebarannya ngelompok berdasarkan hitungan Indeks Morisita dengan nilai perstasiun. Hasil perhitungan pola sebaran hitungan Indeks Morisita Remis pada stasiun I 1,075 dan II 1,208, dan stasiun III 1,092 menunjukkan angka Id $>1$ berarti Penyebaran mengelompok

Pola sebaran pada Pantai Batu Bedaun adalah pola sebaran yang merata sedangkan pada Pantai Beriga pola sebaran Remis cenderung mengelompok. Melihat pola sebaran yang berbeda tersebut menunjukkan adanya perubahan kondisi lingkungan baik sifat fisika dan kimia perairan maupun ketersedian makan serta potensial reproduktif. Remis terdistribusi di dalam substrat perairan secara tidak merata tergantung pada sifat fisika dan kimia substrat.

Berdasarkan hasil penelitian, bahwa nilai parameter dari kedua lokasi penelitian tidak ada perbedaan signifikan, akan tetapi suhu perairan di Pantai Batu Bedaun lebih tinggi dibandingkan dengan Pantai Beriga. Menurut (Rangan, 1996 dalam Riniatsih et al., 2009) menyatakan suhu perairan merupakan salah satu faktor yang dapat mempengaruhi sebaran suatu organisme. Keberadaan jenis dan keadaan seluruh kehidupan komunitas pantai cenderung bervariasi dengan berubahnya suhu, hal tersebut diperkuat oleh pendapat (Hutabarat dan Evans, 1995 dalam Riniatsih et al., 2009) yang menyatakan bahwa suhu di perairan merupakan salah satu faktor penting bagi kehidupan organisme di dalamnya, karena suhu mempengaruhi aktivitas metabolisme maupun perkembangbiakkan.

Dari hasil analisa tekstur sedimen bahwa rata-rata dari stasiun 1, 2, dan 3 pada lokasi Pantai Batu Bedaun mempunyai substrat dasar lempung berpasir, sedangkan stasiun 1, 2, dan 3 pada lokasi Pantai Beriga didominasi oleh substrat dasar pasir. Substrat dasar berpasir menunjukkan pola sebaran remis berkelompok, karena Pantai Beriga merupakan habitat yang paling cocok bagi hidup Remis. Hal tersebut sesuai dengan pendapat Dharma (1988 dalam Riniatsih et al., 2009) yang menyatakan hidup pada daerah pantai dengan substrat dasar pasir yang masih termasuk dalam zona littoral, sedangkan Remis hidup di daerah pantai berpasir atau substrat padat.

Pola sebaran Remis merata menunjukkan bahwa ekosistem di Pantai Batu Bedaun dalam keadaan tidak seimbang. Perbedaan pola sebaran Remis dapat disebabkan oleh adanya substrat dasar perairan yang ditempati. Substrat dasar Pantai Batu Bedaun merupakan substrat dasar pasir berlempung sedangkan di Pantai Beriga memiliki substrat dasar berpasir. Menurut Riniatsih et al., (2009) substrat salah satu indikator yang dapat menunjukkan ketidakseimbangan dalam ekosistem adalah berubahnya sebaran organisme yang ada. Substrat dasar perairan menentukan distribusi dalam suatu perairan karena di dalam substrat terdapat sumber makanan Remis. Karakteristik substrat akan mempengaruhi sebaran dan kelimpahan Remis.

Hasil analisis tekstur subtrat dasar pada 2 lokasi pengamatan yaitu Pantai Batu Bedaun dan di Pantai Beriga terdiri atas pasir, lumpur dan sedikit liat, Analisis tekstur substrat dasar perairan menunjukan bahwa pada Pantai Batu Bedaun merupakan perairan dengan dasar berlempung Pantai Batu Bedaun mempunyai substrat dasar berlempung, substrat berlempung bukan merupakan habitat alami Remis. Menurut Riniatsih et al., (2009) sebaran Remis disubstrat berpasir lebih tinggi jika dibandingkan dengan substrat lempung berpasir, hal ini disebabkan kandungan jenis substrat dan jenis partikel 
merupakan faktor lingkungan yang berpengaruh terhadap kelimpahan Remis, karena masingmasing jenis Remis mempunyai cara hidup yang berbeda yang disesuaikan dengan jenis substrat dasar habitatnya.

Pantai Batu Bedaun memiliki pola sebaran Remis merata, melihat pola sebaran tersebut menunjukkan bahwa ekosistem perairan Pantai Batu Bedaun dalam keadaan tidak seimbang. Salah satu indikator yang dapat menunjukkan ketidakseimbangan dalam ekosistem adalah substrat. Menurut Junaidi et al.,(2010) menyatakan bahwa adanya perubahan kondisi lingkungan baik sifat fisika dan kimia perairan. Remis terdistribusi di dalam substrat perairan secara tidak merata tergantung pada sifat fisika dan kimia meliputi substrat, $\mathrm{pH}$, garam-garam organik, tekstur tanah.

Substrat mempunyai peranan penting bagi kehidupan Remis. Menurut Nybaken (1982 dalam Riniatsih et al., 2009) umumnya Remis hidup di substrat untuk menentukan pola hidup, ketiadaan dan tipe organisme. Ukuran sangat berpengaruh dalam menentukan kemampuan Remis menahan sirkulasi air. Bahan organik dan tekstur sedimen sangat menentukan keberadaan dari Remis. Tekstur sedimen atau substrat dasar merupakan tempat untuk menempel dan merayap atau berjalan, sedangkan bahan organik merupakan sumber makanannya, jika polusi masih sedikit atau bahkan tidak ada maka Remis yang hidup akan jauh lebih banyak dan beragam dengan mempertimbangkan tekstur substrat dasar, kandungan bahan organik pada substrat, untuk tumbuh berkembangnya Remis itu sendiri.

Pantai Beriga memiliki sebaran Remis yang menunjukkan pola sebarannya mengelompok. Menurut Ferdiansyah et al., (2015) menyatakan sifat individu yang cenderung mengelompok tersebut sebagai akibat menanggapi perubahan cuaca dan musim, perubahan habitat dan proses reproduktif. Pola penyebaran ini sangat tidak menguntungkan karena dapat meningkatkan persaingan antar individu dalam mendapatkan makanan dan ruang sebagai tempat hidupnya. Selain itu juga mengatakan pola penyebaran mengelompok dengan tingkat pengelompokan yang bermacam-macam merupakan bentuk penyebaran yang paling umum terjadi karena individu-individu dalam populasi cendrung membentuk kelompok. Penyebaran mengelompok ini diduga karena genus-genus tersebut hanya dapat hidup dengan kondisi lingkungan tertentu atau dapat pula karena adanya penyebaran sumber makanan yang tidak merata.

Menurut Junaidi et al., (2010) menyatakan bahwa adanya sifat individu yang berkelompok disebabkan karena adanya keseragaman habitat sehingga terjadi pengelompokan ditempat yang banyak bahan makanan. Pada umumnya hewan hidup berkelompok, hal ini dilakukan karena adanya kecenderungan untuk mempertahankan diri dari predator dan faktor-faktor lain yang tidak menguntungkan untuk kehidupannya. Organisme yang memiliki kisaran toleransi yang luas akan memiliki penyebaran yang luas juga, sebaliknya organisme yang kisaran toleransinya sempit (sensitif) maka penyebarannya juga sempit.

Dari pengamatan yang dilakukan di Pantai Batu Bedaun diketahui bahwa sebagian besar pola penyebaran populasinya secara merata, hal ini disebabkan karena adanya persaingan yang keras diantara individu dalam populasi, sehingga menuntut adanya pembagian wilayah yang sama. Pantai Beriga memiliki pola penyebaran mengelompok yang disebabkan oleh kabutuhan yang sama akan faktor lingkungan, sebagaimana yang dapat dilihat pada data pengamatan diketiga stasiun banyak sekali terdapat Remis sedangkan di Pantai Batu Bedaun Remis terhitung jumlah nya. Menurut Morton et al., (2002) dalam Braz et al., (2015) faktor penyebaran populasi dapat disebabkan karena dorongan mencari makanan, menghindarkan diri dari predator, pengaruh iklim, terbawa air/angin.

\section{KESIMPULAN}

Berdasarkan hasil penelitian dapat disimpulkan bahwa Kelimpahan populasi Remis (Donax sp.) di Pantai Batu Bedaun Kecamatan Sungailiat berkisar antara $6 \mathrm{ind} / \mathrm{m}^{2}-16 \mathrm{ind} / \mathrm{m}^{2}$. Analisis kelimpahan secara umum menunjukkan tingkat kelimpahan yang rendah, sedangkan di Pantai Beriga Kecamatan Lubuk Besar berkisar antara $151 \mathrm{ind} / \mathrm{m}^{2}$ - $194 \mathrm{ind} / \mathrm{m}^{2}$ dan kelimpahan secara umum menunjukkan tingkat kelimpahan yang cukup tinggi, sedangkan Pola sebaran Remis (Donax sp.) di pantai Batu Bedaun dari ke 3 stasiun dimana Id $<1$ dimana berarti penyebaran spesies merata dan di Pantai Beriga dari ke 3 stasiun dimana angka Id $>1$ berarti Penyebaran mengelompok

\section{DAFTAR PUSTAKA}

Bahri. F. Y. 2006. Keanekaragaman dan kepadatan komunitas moluska di perairan sebelah utara Danau Maninjau. [Skripsi] Fakultas Matematika Dan Ilmu Pengetahuan Alam. Institut Pertanian Bogor

Barus, T. A. 2004. Pengantar limnologi studi tentang ekosistem sungai dan danau. Fakultas Matematika dan Ilmu Pengetahuan Alam. Universitas Sumatera Utara 
Braz J, Carlos S. 2015. Distribuição e densidade do molusco Donax striatus (Linnaeus, 1767) em região estuarina tropical do semiárido brasileiro. Jurnal Biologi Brasil 10(4): 75

Cardoso. 2007. Pertumbuhan dan reproduksi dalam bivalvia: Pendekatan anggaran energi Groningen. Universitas Groningen

Dahuri R, 2003. Paradigma baru pembangunan indonesia berbasis kelautan. Orasi Ilmiah Guru Besar Tetap Bidang Pengelolaan Sumberdaya Pesisir dan Lautan Fakultas Perikanan dan Ilmu Kelautan. Institut Pertanian Bogor.

Dharma D. 2005. Recent dan fossil Indonesia Shells. Institute of Geological Dan Nuclear Sciences Lower Hutt. New Zealand. 264271

Fajri MA. 2014. Asosiasi makrozoobentos dengan terumbu karang di Perairan Turun Aban Kabupaten Bangka. [Skripsi]. Jurusan Manajemen Sumberdaya Perairan Peminatan Ilmu Kelautan. Universitas Bangka Belitung

Ferdiansyah A, Irawan H, Pratomo A. 2015. Pola sebaran bivalvia di zona litoral Kampung Gisi Kabupaten Bintan Provinsi Kepulauan Riau. Fakultas Ilmu Kelautan dan Perikanan. Universitas Maritim Raja Ali Haji

Hartoni, Agussalim A. 2013. Komposisi dan kelimpahan moluska (gastropoda dan bivalia) di ekosistem mangrove Muara Sungai Musi Kabupaten Banyuasin Provinsi Sumatera Selatan. Jurnal Maspari 5(1): 6-15

Hidayanto E, Rofiq A, Sugito H. 2010. Aplikasi portable brix meter untuk pengukuran indeks. Jurnal Bias Berkala Fisika 13(4): 113-118

Irawan I. 2008. Struktur komunitas moluska (gastropoda dan bivalvia) serta distribusinya di Pulau Burung dan Pulau Tikus, Gugusan Pulau Pari, Kepulauan Seribu, Institut Pertanian Bogor

Junaidi E, Sagala EP, Joko. 2010. Kelimpahan populasi dan distribusi Remis (Corbicula sp.) di Sungai Borang Kabupaten Banyuasin. Jurnal Penelitian Sains 13(3): 50-54

Oktaviani N, Nursugi, Rangga LS. 2014. Pengukuran garis pantai menggunakan metode rtk (gps tracking) dan metode tongkat penduga. Jurnal Ilmiah Geomatika 20(2): 109-114

Ritniasih I, Edi KW. 2009. Substrat dasar dan parameter oseanografi sebagai penentu keberadaan gastropoda dan bivalvia di Pantai Sluke Kabupaten Rembang. Jurnal Ilmu Kelautan 14(1): 50-59
Ritniasih I, Widianingsih. 2007. Kelimpahan dan pola sebaran kerang kerangan (bivalve) di ekosistem padang lamun, Perairan Jepara. Jurnal Ilmu Kelautan 12(1): 53-58

Risawati D. 2002. Struktur komunitas moluska (gastropoda dan bivalvia) di hutan mangrove muara Sungai Donan kawasan BKPH rawa timur, KPH Banyumas Cilacap, Jawa Tengah. [Skripsi]. Program Studi Ilmu Kelautan. Institut Pertanian Bogor

Riyanto. 2004. Pola distribusi populasi keong mas (Pomacea Canaliculata L.) di Kecamatan Belitang Oku. Sriwijaya, Jurnal Ilmu Kelautan 37(1): 70-75

Romimohtarto K, Juwana S. 2009. Biologi Laut: Ilmu Pengetahuan Tentang Biota Laut. Penerbit Djambatan. Jakarta

Setyobudiandi I, Sulistiono, Yulianda F, Kusmana C, Hariyadi S, Damar A, Sembiring A, Bahtiar. 2009. Sampling dan analisis data perikanan dan kelautan terapan metode pengambilan contoh di wilayah pesisir dan laut. Fakultas Perikanan dan Ilmu Kelautan Institut Pertanian Bogor

Sitorus D. 2008. Keanekaragaman dan distribusi bivalvia serta kaitannya dengan faktor fisik-kimia di perairan Pantai Labu Kabupaten Deli Serdang. [Tesis]. Fakultas MIPA. Universitas Sumatera Utara

Sousa R, Antunes C, Guilhermino L. 2008. The distribution of the Asian clam Corbicula fluminea and its potential to spread in Ireland. Journal Compilation 44(2): 85-94

Stevanus, Setiadikarunia D. 2013. Alat pengukur kelembaban tanah berbasis Mikrokontroler PIC 16F84. Jurusan Teknik Elektro. Universitas Kristen Maranatha

Verawati. 2016. Analisis kualitas air laut di Teluk Lampung. [Tesis]. Fakultas Teknik. Universitas Lampung 